\title{
A Case of Cardiopulmonary Arrest with ST Elevation: What was the Main Cause?
}

\author{
St Elevasyonlu Kardiyopulmoner Arrest Olgusu:Temel Sebep Ne Idi?
}

Emre Salçın, Can Özen, Serhad Ömercikoğlu, Merter Gümüşel, Serkan Emre Eroğlu, Haldun Akoğlu, Özge Onur

Clinic of Emergency Medicine, Marmara University Pendik Training and Research Hospital, İstanbul, Turkey

\section{ABSTRACT}

Introduction: Twenty percent of all strokes are hemorrhagic and $50 \%$ of hemorrhagic strokes are because of subarachnoid hemorrhage (SAH). Cardiac abnormalities and electrocardiographic (ECG) changes are commonly seen after SAH. Here, we present a patient with a sudden loss of consciousness, respiratory arrest, and diffuse ST segment changes in ECG.

Case Report: A 52-year-old wife, who had only hypertension in her medical history, learnt that her husband had a blunt trauma to the head and a decompressive craniectomy was performed. While he was sent to an intensive care unit, his wife collapsed just outside the emergency department (ED). The female patient had a respiratory arrest and then entered ventricular fibrillation. After Cardiopulmonary resuscitation (CPR) and $200 \mathrm{~J}$ defibrillation, the monitor showed an atrial fibrillation rhythm and the pulse returned. The ECG showed elevations in ST segments and a percutaneous coronary intervention was planned. Meanwhile, emergency physicians suspected an intracranial pathology and a computed tomography (CT) scan revealed a diffuse SAH.

Conclusion: The clinical findings and the patient history are very important to avoid malpractice. If the physicians do not give sufficient attention to these areas, the patients can easily be mistreated.

Keywords: Subarachnoid hemorrhage, ECG changes, aneurysm Received: 07.01.2015 Accepted:31.03.2015

Available Online Date: 24.04.2015

\section{ÖZET}

Giriş: Tüm inmelerin \%20'si hemorajik ve hemorajik inmelerin \%50'si subaraknoid kanamadır. Kardiyak anormallikler ve elektrokardiyografik değişikler subaraknoid kanama sonrası sık görülür. Bizbu vakada ani gelişen bilinç kaybı sonrası önce solunum arresti, sonra kardiyak arrest olan ve elektrokardiyografisinde difüz ST segment değişiklikleri görülen bir hastayı sunacağız.

Olgu Sunumu: 52 yaşında, özgeçmişinde sadece hipertansiyonu olan bayan hasta eşinin künt kafa travması sonrası dekompresif kraniektomi yapıldığını öğrenmiş. Eşi operasyon sonrası yoğun bakıma gönderilirken acil servisin hemen dışında yere yığılmış. Acil servise alınan hastada solunum arresti geliştiği görüldü. Ardından ventriküler fibrilasyona giren hastada kardiyopulmoner resüsitasyona başlandı ve 200 joule ile defibrile edildi. Başarılı resüsitasyon sonrası nabız alındı ve elektrokardiografide atrial fibrilasyon ritmi ve yaygın ST segment elevasyonları görüldü. Perkütan koroner girişim planlanan hastaya acil doktorlarının şüphesi üzerine kranial bilgisayarlı tomografi çekildi. Sonuç şaşırtıcı değildi, hastada yaygın subaraknoid kanama saptandı.

Sonuç: Klinik bulgular ve hastanın öyküsü, malpraktisin önlenmesinde çok önemlidir. Hekimler bunlara yeterli dikkati göstermezse, hastalar kolaylıkla yanlış tedavi edilebilir.

Anahtar Kelimeler: Subaraknoid kanama, EKG değişiklikleri, anevrizma

Geliş Tarihi: 07.01.2015 Kabul Tarihi: 31.03.2015

Çevrimiçi Yayın Tarihi: 24.04.2015

\section{Introduction}

The ST elevation myocardial infarction (STEMI) is one of the most important mortality causes worldwide (1). STEMI is easily diagnosed, often within seconds, with the help of the patient history and an electrocardiography (ECG). Time has a critical importance in treatment and sometimes physicians wish to take a percutaneous coronary intervention decision as soon as possible (2). 
Although ST segment elevation is the main criteria for STEMI, a physician must always keep in mind the other conditions that can mimic this deadly condition in emergency settings. ST segment elevation can be seen in various causes such as myocarditis, pericarditis, Brugada syndrome, coronary aneurysm, aortic stenosis, cardiomyopathies, aortic dissection, and intracranial pathologies (3).

Here, we present a patient with a sudden loss of consciousness, respiratory arrest, and diffuse ST segment changes in ECG. It was initially diagnosed as STEMI; however, it was learned that the main cause of this ST segment elevation was subarachnoid hemorrhage $(\mathrm{SAH})$ after consultation with the emergency physicians.

\section{Case Report}

A 52-year-old female patient had collapsed just outside the emergency department (ED). She was brought in with a Glasgow Coma Score (GCS) of 3, central cyanosis, and a gasping breathing pattern. She only had hypertension in her medical history. She learnt that her husband had a blunt trauma to the head because of a fallen object at his workplace. He had an open skull fracture in the left frontotemporal region. A decompressive craniectomy was performed. His wife had a respiratory arrest when he was sent to an intensive care unit. While a crash intubation was being performed, the patient was monitored and ventricular fibrillation could be seen on the monitor. She suffered a cardiac arrest within seconds and the team started cardiopulmonary resuscitation (CPR). The patient was defibrillated with $200 \mathrm{~J}$ three times in the following cycles. After three cycles of CPR, the monitor showed an atrial fibrillation (AF) rhythm and the pulse returned. After CPR, blood pressure was 216/127 $\mathrm{mmHg}$. The ECG showed ST segment elevations in anteroseptal leads (V1, V2, V3) and ST segment depressions in inferolateral leads (Figure 1).

The patient was referred to the cardiology department with a possible diagnosis of STEMI due to emotional stress. Meanwhile, the laboratory results arrived. Arterial blood gas analysis revealed the following: $\mathrm{pH} 7.445, \mathrm{SO}: 73.1 \% / \mathrm{L}, \mathrm{HCO}_{3} 19 \mathrm{mmol} / \mathrm{L}(21-28 \mathrm{mmol} / \mathrm{L})$, $\mathrm{K} 3.23 \mathrm{mEg} / \mathrm{L}$ (3.4-4.5 mEg/L), and lactate $3.1 \mathrm{mmol} / \mathrm{L}$. Troponin and CK-MB levels were within normal range. Cardiologists planned a percutaneous transluminal coronary angiography (PTCA).

In addition to this, we performed cranial computed tomography (CT) (Somatom Emotion 16; Siemens, Erlangen, Germany) to exclude other pathologies. The $\mathrm{CT}$ revealed a diffuse $\mathrm{SAH}$ and an aneurysm in the right middle cerebral artery (MCA) (Figure 2). The patient, like her husband, was referred to the neurosurgery department. The neurosurgeons admitted her to an internal care unit (ICU). Control troponin t-hs levels were $732.20 \mathrm{ng} / \mathrm{L}$ (normal range 0-14 ng/L) after $6 \mathrm{~h}$. During her admission, the patient developed hypotension and was in need of noradrenalin infusion. Three days later, there were no improvement in brain stem reflexes and apnea test was positive. Brain death was confirmed by neurosurgery; neurology, cardiology, and mechanical support was ceased. The patient was announced dead. Written informed consent was obtained from the patient's relative who participated in this case.

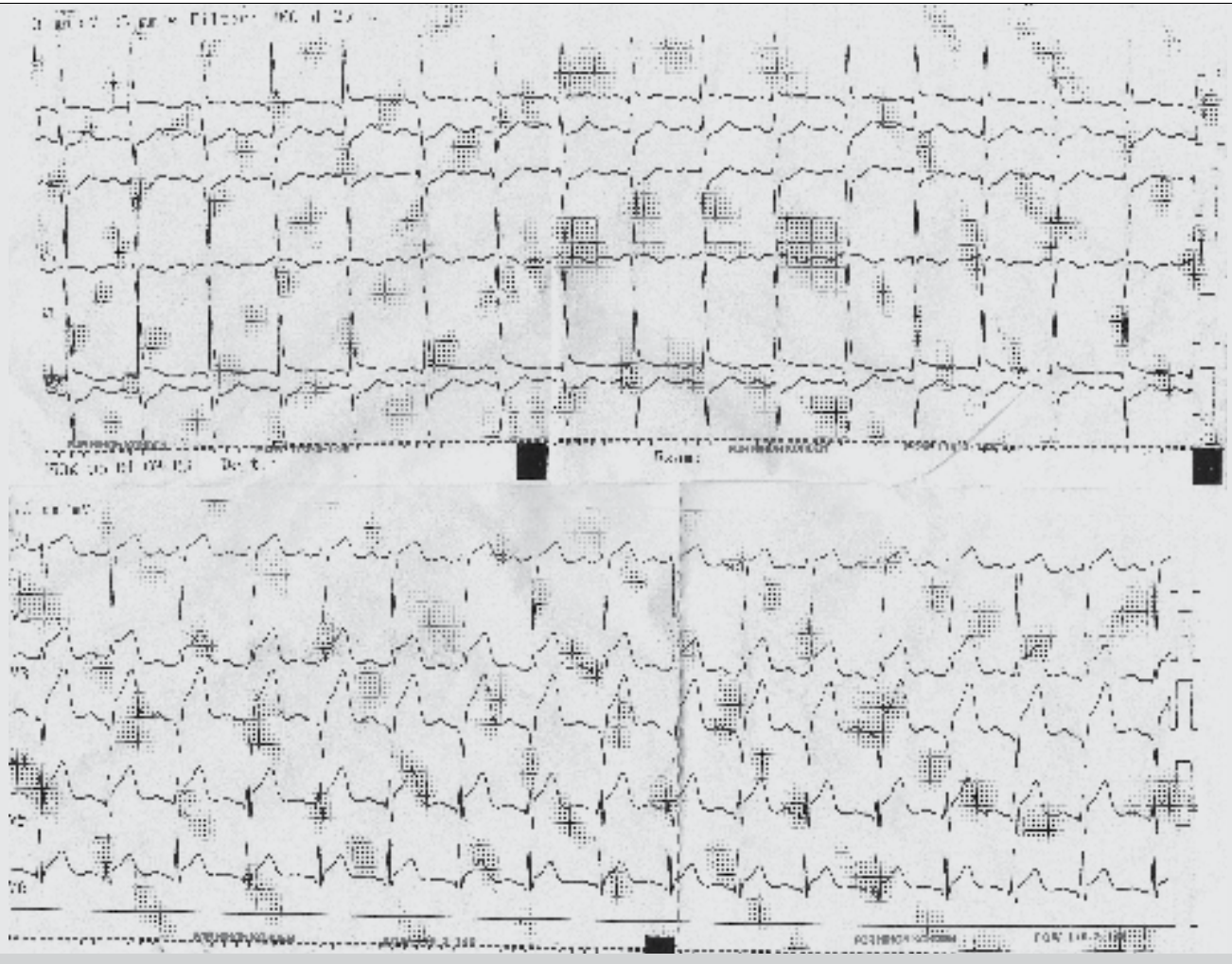

Figure 1. ECG of the patient after defibrillation: ST segment elevation in anteroseptal leads and depression in lateral leads 


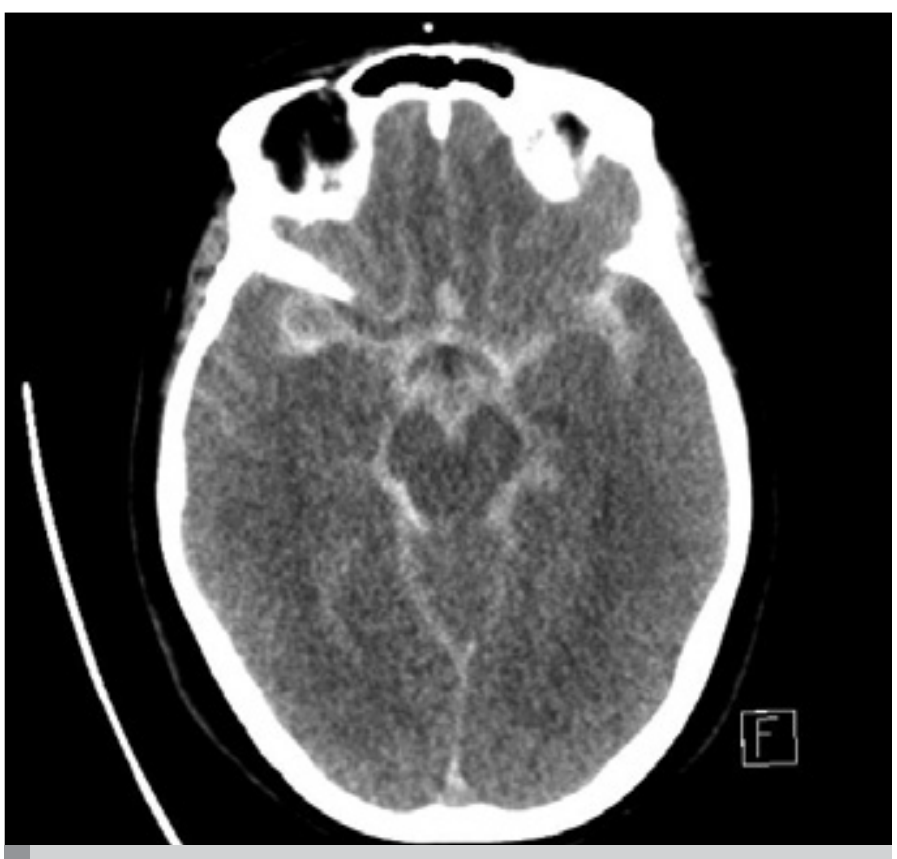

Figure 2. Cranial CT before PTCA shows diffuse subarachnoid hemorrhage and an aneurysm in the right MCA

\section{Discussion}

The most common cause of SAH is ruptured saccular aneurysms. Other common causes of SAH are trauma, arteriovenous malformation, vasculitis, intracranial arterial dissections, amyloid angiopathy, hemorrhagic diathesis, and drug abuse. ECG changes in SAH can be seen commonly and as the SAH severity increases, ECG changes may be seen more prominently and commonly (4). Most commonly seen ECG changes are ST segment depression, QT interval elongation, deep symmetrical $T$ waves, and distinctive $U$ waves (5). In SAH cases, fatal rhythms like torsades can also be seen in addition to atrial fibrillation and flutter. In case of subarachnoid hemorrhage, the ECG can mimic acute coronary syndrome (6).

The average age at which SAH is mostly diagnosed is, as in our case, 55 years. Hypertension is known to be the most important risk factor for SAH. Instant blood pressure increase, physical exercise, caffeine consumption, acute emotional stress (as in our case), and sexual activity are triggering factors for SAH (7).

In an aneurysm rupture, the first symptom mostly involves the sudden onset of headache ( $97 \%$ of cases) and loss of consciousness can be seen, as in our case. In addition, seizures, nausea, vomiting, and meningismus symptoms can be seen (8).

Subendocardial ischemia is a poor prognosis finding in SAH patients and must be treated aggressively (4). In a real myocardial infarction case, an increase in myocardial necrosis, specific and more sensitive markers of CK-MB, and serum troponin I (>0.1 $\mu \mathrm{g} / \mathrm{L}$ ) levels is seen (9). ECG abnormalities and clinical findings of left ventricular dysfunction is associated with elevated troponin I levels. In our case, ST segment changes were seen in the initial ECG, and first troponin t-hs levels were within normal range. However, the control cardiac biomarkers elevated after $6 \mathrm{~h}$. This increase may also be due to defibrillation and CPR. However, the control troponin t-hs levels were $1376.16 \mathrm{ng} / \mathrm{L}$ after $12 \mathrm{~h}$. In the second ECG, ST segment elevations were resolved but ST depressions were still present.

An acute increase in troponin levels after SAH is a risk factor for cerebrovascular and cardiopulmonary complications (4). In a 253 patient SAH case series, serial troponin level measurements were performed and ECG controls were maintained to demonstrate the cardiac damage, and increased peak troponin levels were found to be related to left ventricular disfunction, pulmonary edema, hypotension in need of vasopressor support (as in our case), and increased cerebral ischemia related to vasospasm (10). These findings were confirmed with a meta-analysis of 25 studies, which includes $2960 \mathrm{SAH}$ patients. In this analysis, increased troponin levels are related to increased mortality and poor functional conclusion (4).

Patients with SAH may also present with nausea, vomiting meningismus, retinal subhyaloid hemorrhages, altered mental status, or syncope. Our patient presented with a sudden loss of consciousness, and cardiac arrest occurred after she collapsed following a respiratory arrest. Although ECG after resuscitation showed ST segment elevations, the clinical findings did not match STEMI. Because STEMI is not expected to cause respiratory arrest, an intracranial pathology was suspected and a cranial CT was obtained. CT revealed SAH due to a ruptured MCA aneurysm. PTCA and thrombolytic therapy was rejected and a possible malpractice was prevented.

\section{Conclusion}

Cardiac abnormalities and ECG changes are commonly seen after $\mathrm{SAH}$. Patients with a sudden loss of consciousness and respiratory arrest should be evaluated thoroughly before undergoing an invasive therapy such as PCl even if they have ST changes in their ECGs. Any other causes, including intracranial pathologies, should be ruled out first to ensure the wellbeing of the patient as well as to avoid malpractice.

Informed Consent: Written informed consent was obtained from the patient's relative who participated in this case.

Peer-review: Externally peer-reviewed.

Author Contributions: Concept - S.E.E., O.O.; Supervision - S.E.E., O.O., H.A.; Data Collection and/or Processing - S.Ö., M.G., C.Ö.; Analysis and/ or Interpretation - E.S., S.Ö.; Literature Review - E.S., S.Ö.; Writer - E.S., C.Ö., M.G.; Critical Review - S.E.E., Ö.O.

Conflict of Interest: No conflict of interest was declared by the authors.

Financial Disclosure: The authors declared that this study has received no financial support. 
Hasta Onamı: Hasta onamı bu çalışmaya katılan hastanın yakınından alınmıştır.

Hakem değerlendirmesi: Dış bağımsız.

Yazar Katkıları: Fikir - S.E.E., Ö.O.; Denetleme - S.E.E., O.O., H.A.; Veri toplanması ve/veya işlemesi - S.Ö., M.G., C.Ö.; Analiz ve/veya yorum - E.S., S.Ö.; Literatür taraması - E.S., S.Ö.; Yazıyı yazan - E.S., C.Ö., M.G.; Eleştirel İnceleme - S.E.E., Ö.O

Çıkar Çatışması: Yazarlar çıkar çatışması bildirmemişlerdir.

Finansal Destek: Yazarlar bu çalışma için finansal destek almadıklarını beyan etmişlerdir.

\section{References}

1. Lloyd-Jones D, Adams RJ, Brown TM, Carnethon M, Dai S, De Simone G, et al; American Heart Association Statistics Committee and Stroke Statistics Subcommittee. Executive summary: heart disease and stroke statistics-2010 update: a report from the American Heart Association. Circulation 2010; 121: 948-54. [CrossRef]

2. Bradley EH, Herrin J, Wang Y, Barton BA, Webster TR, Mattera JA, et al. Strategies for reducing the door-to-balloon time in acute myocardial infarction. N Engl J Med 2006; 355: 2308-20. [CrossRef]

3. Gu YL, Svilaas T, van der Horst IC, Zijlstra F. Conditions mimicking acute ST-segment elevation myocardial infarction in patients referred for primary percutaneous coronary intervention. Neth Heart J 2008; 16 325-31. [CrossRef]

4. van der Bilt IA, Hasan D, Vandertop WP, Wilde AA, Algra A, Visser FC, et al. Impact of cardiac complications on outcome after aneurysmal subarachnoid hemorrhage: a meta-analysis. Neurology 2009; 72: 63542. [CrossRef]

5. Singer RJ, Ogilvy CS, Rordorf G. Etiology, clinical manifestations, and diagnosis of aneurysmal subarachnoid hemorrhage. UpToDate ${ }^{\oplus}, 2013$ www.uptodate.com/contents/etiology-clinical-manifestations-anddiagnosis-of-aneurysmal-subarachnoid-hemorrhage. Last accessed 28/03/2015

6. Yüce $M$, Davutoğlu V, Alptekin M, Yavuz F, Alıcı MH, Yıldırım C. Akut koroner sendromu taklit eden subaraknoid kanama vakası. AKATOS 2010; 1: 31-3.

7. Vlak MH, Rinkel GJ, Greebe P, van der Bom JG, Algra A. Trigger factors and their attributable risk for rupture of intracranial aneurysms: a casecrossover study. Stroke 2011; 42: 1878-82. [CrossRef]

8. Gorelick PB, Hier DB, Caplan LR, Langenberg P. Headache in acute cerebrovascular disease. Neurology 1986; 36: 1445-50. [CrossRef]

9. Schneider HJ, Kreitschmann-Andermahn I, Ghigo E, Stalla GK, Agha A Hypothalamopituitary dysfunction following traumatic brain injury and aneurysmal subarachnoid hemorrhage: a systema-tic review. JAMA 2007; 298: 1429-38. [CrossRef]

10. Naidech AM, Kreiter KT, Janjua N, Ostapkovich ND, Parra A, Commichau C, et al. Cardiac tropo-nin elevation, cardiovascular morbidity, and outcome after subarachnoid hemorrhage. Circulation 2005; 112: 28516. [CrossRef] 